\title{
Striking examples of the steel uses in the civil construction of the city of São Paulo (Brazil)
}

\begin{abstract}
Background: The steel allowed the civil construction to gain in strength, lightness and in the larger dimension of the spans between supports. Whether as a component of reinforced concrete, as a metal structure, as a closure or frame, steel offers numerous advantages to construction allowing for bolder architectural projects, as its history in Brazil shows, like the examples of "Santa Efigênia" Viaduct, the "América" garage building, the São Paulo Art Museum (MASP) and the "Octavio Frias de Oliveira" cable-stayed bridge, using pre stressed cables, the endless uses for steel in construction has been perfected by its lightness, fast and precise assembly and the possibility of reuse in another local.
\end{abstract}

Volume 5 Issue 2 - 2019

\section{Vanessa Meloni Massara}

Adjunct researcher PhD, University of São Paulo, Brazil

Correspondence: Vanessa Meloni Massara PhD, Adjunct researcher, polytechnic school, University of São Paulo, Brazil,Tel +55II 97567 9973, Email vmmassara@usp.br

Received: August 19,2019 | Published: August 30, 2019

Keywords: steel, civil construction, reinforced concrete, metallic structures, pre stressed concrete

Abbreviations: CSN, companhia siderúrgica national; MASP, são paulo art museum; ABNT, Brazilian association of technical standards; ASTM, American society for testing and materials; ASME, American Society of mechanical engineers; ISO, international organization for standardization

\section{Introduction}

Construction has a wide range of materials that are used in various uses, from those that make up mortars such as sand and cement to more complex materials, which combined have structural profile, such as steel profiles. Steel adapts to various uses in various areas of economic activity such as mechanical and marine engineering. In this work the approach of its application concerns the civil construction, given its resistance, lightness, ease of assembly and aesthetic suitability in architectural projects.

\section{Material and methods}

This brief analysis presents four important civil engineering works in the city of São Paulo (Brazil) where the use of steel is predominant over a period of 100 years:
a. "Santa Efigênia" Viaduct.
b. "América" Garage Building.
c. São Paulo Art Museum (MASP).
d. "Octavio Frias de Oliveira" cable-stayed bridge.

\section{Results}

In Brazil, a first example of steel construction is the "Santa Efigênia" Viaduct, built in the early 1910s. The work was made of rolled steel, where vertical mullions rest directly on the arches and are equidistant of $3,665 \mathrm{~m}$, constituting 15 panels, with a stringer interconnecting the tops of the mullions in the longitudinal direction; and with transverse frameworks, interconnecting the four parallel arches, plus vertical and horizontal braces. ${ }^{1}$ Figure 1 shows the longitudinal profile of this viaduct that had its structure brought from Belgium, ready to be assembled in 1913, undergoing renovations in 1950 (due to the special corrosion of the transvesine, spars and auxiliary bars).

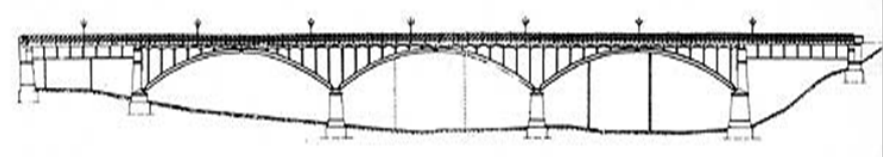

Figure I Longitudinal profile of the "Santa Efigênia" Viaduct.'

A second example is the "América" garage building, the first building in Brazil built with metallic structures (16floors), manufactured and assembled by Brazilians in 1954 with the function of being a vertical garage in downtown São Paulo. In an uneven terrain, fanning and descending more than $18 \mathrm{~m}$, hindering the land movement for the foundations and, for the first time in Brazil, the solution of metal pile foundations of the National Steel Company (known in Portuguese as Companhia Siderúrgica National - CSN), with of "2L" profiles welded by the flaps, forming a coffin, and constituting a major structural challenge for that time. ${ }^{2}$ The profiles were made of special alloy with high copper content to prevent corrosion.

The assembly of this building was hand made using a mobile boom mast on a platform with four metal wheels and two manual winches with levers and ropes, an air compressor and riveting hammers (Figure 2A). As an example of reinforced and pre stressed concrete, the construction of the São Paulo Art Museum (MASP) in São Paulo's capital and its huge gap is an example of the combination of steel and concrete and their vast structural possibilities (Figure 2B).

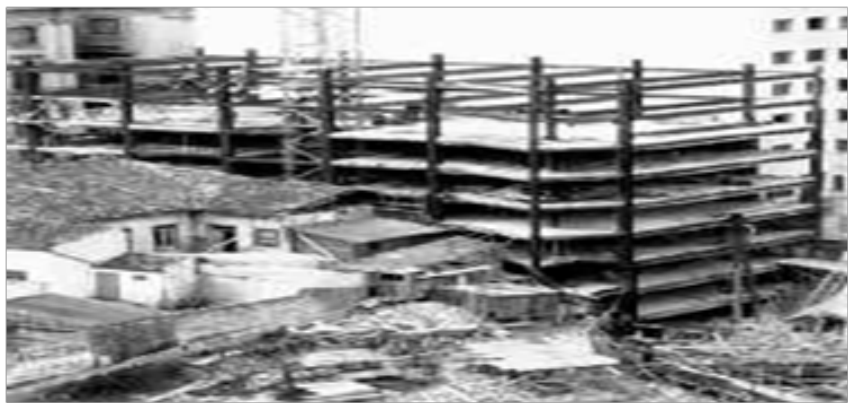

2(A) 


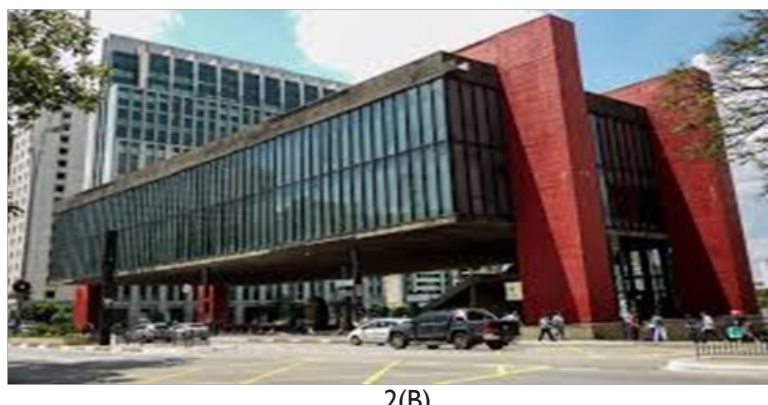

2(B)

Figure 2 Examples of the steel in Brazilian civil construction. (A) Metal structure of the "América" garage building.' (B) As a component of pre stressed concrete of MASP beams. ${ }^{3}$

In the whole of this museum there are two external beams (in red), but the real ones responsible for much of the support is made by two beams internal to the suspended box. The four beams are pre

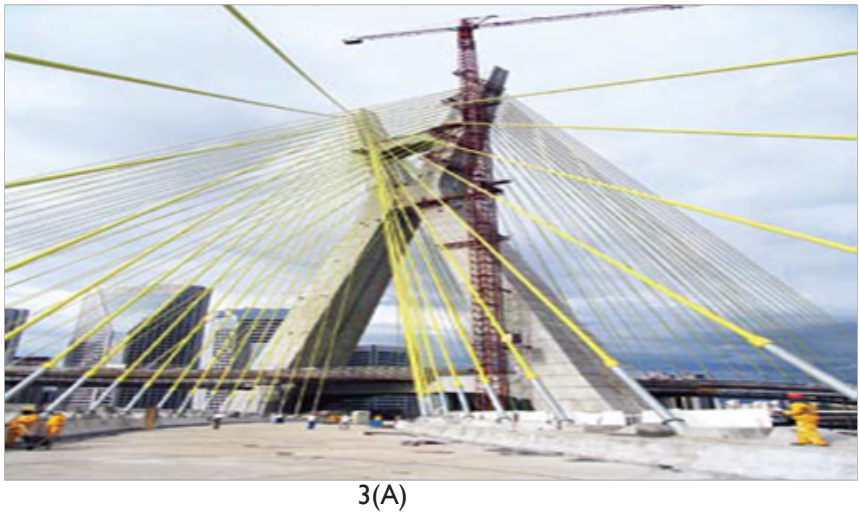

stressed by a pre stressing system created by engineer José Carlos de Figueiredo Ferraz (Polytechnic School of the University of São Paulo, Brazil). ${ }^{3}$

The pre stressing of the beams was performed over a period of several weeks on hundreds of cables until reaching the compression determined for each beam by injecting cement cream into each sheath surrounding the cables. Another steel example is the cable-stayed bridge "Octavio Frias de Oliveira" (also in São Paulo), inaugurated in 2008 (Figure 3A). The central support starts with 4high pillars with $12 \mathrm{~m}$ each one, with variable rectangular section, being connected transversely by a ribbed slab and longitudinally by a pre stressed concrete platform composed of two beams and a slab.

The 4 stayed spans are supported by 18pairs of stays, in a total of 144 stays formed by a number of strands ranging from 10 (near the central mast) to 25 (near the extreme supports). All the staging consumed about 375 thousand meters of ropes, equivalent to 462 tons of steel, ${ }^{4}$ (Figure 3B).

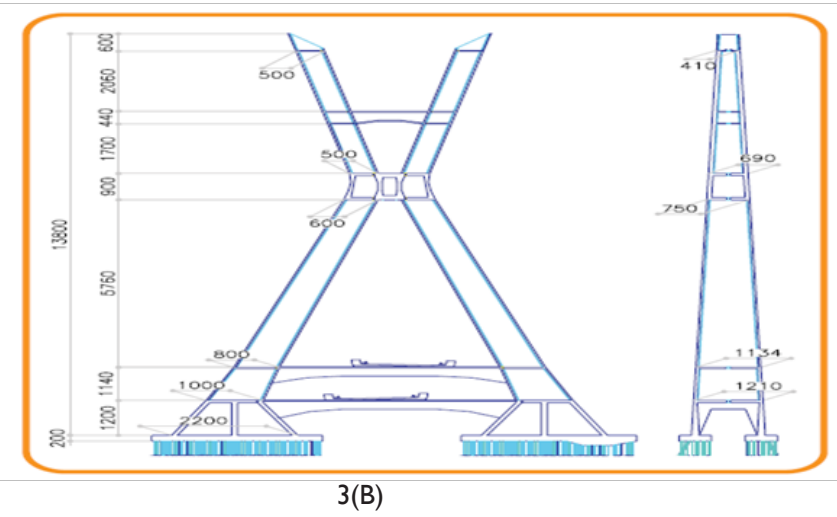

Figure 3 (A) "Octavio Frias de Oliveira" cable-stayed bridges. (B) Main dimensions of the central support. ${ }^{4}$

\section{Discussion}

According to the São Paulo Engineering Institute, ${ }^{5}$ special attention should be given to the possibility of atmospheric corrosion. In order to counteract this, there are special steels with added protection, so-called wheathering steel, created in the United States in the 1930s, first used on railways and then as a coating, combining high mechanical strength with atmospheric corrosion resistance. Commercially they are called Corten and in Brazil they are widely used in civil construction in the form of plates, coils and welded profiles. Steel assemblies in Brazil are standardized by national (Brazilian Association of Technical Standards, ABNT) and international guidelines such as the American Society for Testing and Materials (ASTM), the American Society of Mechanical Engineers (ASME), the International Organization for Standardization (ISO) and EUROCODE for Building.

\section{Conclusion}

It is concluded that this material has great versatility, allowing unusual architectural solutions when combined with concrete and when used in a pre stressed manner, allowing large spans and slender structures and, alone, as a metal structure, supporting large loads, as shown in the examples of this text with important constructions in the capital of the state of São Paulo (Brazil), such as the centenary
"Santa Efigenia" Viaduct, the São Paulo Art Museum (MASP), the "América" garage and, more recently, the cable-stayed bridge "Octavio Frias de Oliveira", always providing through its mechanical properties, interesting aesthetic effects in its structures.

\section{Acknowledgments}

None

\section{Conflicts of interest}

There are no conflicts of interest.

\section{References}

1. Metalica. History of the "Santa Efigênia" Viaduct. 2019(a).

2. Metalica. First metal structure building in Brazil. 2019(b).

3. Suzuki M, Rochlitz R. Architecture classics: MASP. 2014.

4. Ribeiro CF, Nogueira Neto HA. Steel in concrete works: the "Real Parque complex". Revista Concreto. 2008;36(50):25-29.

5. The use of steel in construction. Brrazil: Engineering Institute of São Paulo; 2015. 